\title{
OD BIBLIJNEJ WIEŻY BABEL DO WSPÓŁCZESNEGO „POMIESZANEGO ŚWIATA”*
}

\section{„Pomieszany świat” - wyjaśnienie pojęcia}

$\int_{\text {ponm }}$ odczas kilkunastu wyjazdów badawczych w zachodnie i centralne rejony Białorusi, wśród mieszkających tam osób należących do polskiej mniejszości, zetknęłam się z niezwykle ciekawym pojęciem: pomieszany świat (także: zmieszany świat). Jego białoruskim odpowiednikiem jest mjaszany swiet ${ }^{1}$.

Termin pomieszany świat (mjaszanyswiet) stosowany jest najczęściej przez mieszkańców Białorusi ${ }^{2}$ w odniesieniu do znanych im przestrzeni zamieszkałych przez różne grupy etniczne/narodowe, językowe i wyznaniowe

* Część zawartych w tym artykule informacji i propozycji badawczych została przeze mnie przedstawiona we wcześniejszych pracach, wykazanych w Bibliografii. Chciałam jednak wrócić do tej problematyki, by rozwinąć pewne interesujące, według mnie, wątki, wzbogacając je o wyniki najnowszych badań i przemyśleń.

${ }^{1} \mathrm{Na}$ ten temat patrz np.: T. Ivanova, „Mjašanaja mova - mjašany svet”, [w:] Pogranicza Białorusi w perspektywie interdyscyplinarnej, pod red. E. Smułkowej i A. Engelking, Wydawnictwo DiG, Warszawa 2007, s. 225-229; I. Kabzińska, Wśród „kościelnych Polaków”. Wyznaczniki tożsamości etnicznej (narodowej) Polaków na Białorusi, Letter Quality, Warszawa 1999, s. 148-151; Tejże, „Pomieszany świat” jako kategoria opisu etnologicznego/antropologicznego, „Etnografia Polska” 2009, z. 1-2, s. 21-45; E. Smułkowa, Wokół pojęcia pogranicza. Wschodnie i zachodnie pogranicze Białorusi w ujęciu porównawczym, [w:] Pogranicza Białorusi w perspektywie interdyscyplinarnej, pod. red. E. Smułkowej i A. Engelking, Wydawnictwo DiG, Warszawa 2007, s. 5-14; D. Życzyńska-Ciołek, Pomieszany świat, „Polska Sztuka Ludowa. Konteksty” 1996, nr 3-4, s. 203-208.

2 Terminem tym posługują się przede wszystkim osoby starsze, urodzone przed drugą wojną światową, W publikacjach nie znalazłam informacji mówiących o tym czy jest on znany młodszym generacjom. Osobiście nie zetknęłam się z nim podczas rozmów z młodzieżą i osobami reprezentującymi średnie pokolenie. 
(badacz określiłby te obszary mianem pogranicza kulturowego). Bardzo ważne jest tu zarówno sąsiedztwo różnych grup, jak i możliwość przekraczania granic etniczno-kulturowych. Dla pomieszanego świata charakterystyczne są liczne małżeństwa mieszane, różnie oceniane przez członków poszczególnych grup ${ }^{3}$. Jego wyróżnikiem jest także język mieszany, mieszana mowa (biał. mjaszanaja mowa), zwany również przez mieszkańców Białorusi językiem prostym, mowq prostą, „(...) językiem chłopski[m], wioskowy[m], domowy[m], miejscowy[m], tutejszy[m], nasz[ym] [lub/i] sw[oim]"4. Ich zdaniem, stanowi on „zlepek kilku innych "prawdziwych“ języków”5 rosyjskiego, polskiego, białoruskiego. Są one zarazem uważane za "czyste”, „kulturalne”, języki ludzi wykształconych, mieszkających w miastach ${ }^{6}$. Określenie język mieszany/prosty odpowiada używanym przez badaczy terminom: "gwara, dialekt czy substandard"7. Terminem mjaszanaja mowa określana jest również tzw. trasjanka - specyficzne połączenie rosyjskiego i białoruskiego ${ }^{8}$, którą posługują się głównie mieszkańcy miast.

Moim zdaniem, termin pomieszany świat może być stosowany w pracach naukowych np. do opisu zjawisk takich jak: pogranicze kulturowe, wielokulturowość, multikulturalizm, migracje i ich następstwa, kontakty międzykulturowe, przestrzenie pośrednie. Zgodnie z jego znaczeniem, można go również stosować do opisu zmian, zwłaszcza gwałtownych, ich mechanizmów, przyczyn i skutków. Wspomniany termin wzbogaca terminologię, jaką posługują się badacze, pozwala też na łączenie różnych perspektyw, np. określanych mianem emic (perspektywa wewnętrznego interpretatora rzeczywistości) i etic (perspektywa zewnętrznego obserwatora) ${ }^{9}$.

o pomieszaniu mówią mieszkańcy wielu pogranicz etniczno-kulturowych, zjawisko to nie jest więc charakterystyczne jedynie dla Białorusi. Pojęcie mieszani ludzie (mjaszanyja liudzi) używane jest np. przez

${ }^{3}$ Na ten temat patrz np.: I. Kabzińska, Wśród „kościelnych Polaków”..., s. 118-120; D. Życzyńska-Ciołek, dz. cyt., s. 204-205.

${ }^{4}$ A. Engelking, Kołchoźnicy. Antropologiczne studium tożsamości wsi białoruskiej przełomu XX i XXI wieku, Wydawnictwo Naukowe Uniwersytetu Mikołaja Kopernika, Toruń 2012, s. 262.

5 Tamże, s. 263.

${ }^{6}$ Więcej patrz: A. Engelking, dz. cyt., s. 263-265; I. Kabzińska, Wśród „kościelnych Polaków”..., s. 66-69; A. Zielińska, Prestiż i funkcje języka polskiego w okolicach Baranowicz na Białorusi, „Etnografia Polska” 1993, z. 2, s. 20; D. Życzyńska-Ciołek, dz. cyt., s. 203.

7 A. Engelking, dz. cyt., s. 262.

${ }^{8}$ O synonimiczności określeń mjaszanaja mowa i trasjanka patrz: T. Ivanova, dz. cyt., s. $225-227$.

${ }^{9}$ Więcej na ten temat patrz: I. Kabzińska, „Pomieszany świat”... 
przedstawicieli mniejszości białoruskiej na Łotwie (rejon krasławski). W ten sposób określają oni (ogólnie) ludność pogranicza kulturowego oraz osoby o złożonej identyfikacji etnicznej/narodowej ${ }^{10}$. Mieszkańcy Ukrainy mówią o zmieszanej krwi. Określają się również mianem zmieszanych ${ }^{11}$. Występuje tu także pojęcie zmieszany język ${ }^{12}$. W taki sposób określana jest przede wszystkim „mieszanka” ukraińskiego i rosyjskiego, używana przez znaczną część ludności kraju, zwłaszcza zamieszkującą jego wschodnie obszary. Zdaniem Elżbiety Smułkowej, „[ś]wiadomość »mieszania się« dotyczy głównie tożsamości i języka"13, inni badacze uważają jednak, że pomieszany świat to także przestrzeń, w której przenikają się różne tradycje i wzory kulturowe ${ }^{14}$ (zdecydowanie podzielam to zdanie).

Określenie pomieszany świat używane przez mieszkańców Białorusi jest nie tylko synonimem pogranicza kulturowego ${ }^{15}$. Stosuje się je również do opisu sytuacji związanych ze zmianami dotychczasowego porządku ${ }^{16}$. Zmiany te mają najczęściej gwałtowny przebieg, są niespodziewane, radykalne, towarzyszy im poczucie zagrożenia, braku stabilizacji. Ich przykła-

${ }^{10}$ M. Jankowiak, Kilka uwag o czynnikach kształtujących tożsamość narodowq mniejszości białoruskiej na Łotwie (na przykładzie rejonu krasławskiego), [w:] Tożsamość - Język - Rodzina. Z badań na pograniczu słowiańsko-bałtyjskim, pod red. A. Engelking, E. Golachowskiej i A. Zielińskiej, Instytut Slawistyki PAN, Warszawa 2008, s. 90.

${ }^{11}$ L. Mróz, Swoi wśród innych, [w:] Polacy na Podolu, pod red. H. Strońskiego, Stowarzyszenie Uczonych Polskich Ukrainy, Kijów 2004, s. 268. Przed wieloma laty na problemy związane z identyfikacją mieszkańców pogranicza zwrócił uwagę Robert E. Park; R. E. Park, Human Migration and the Marginal Man, „American Journal”, vol. 33. 1928, nr 6, s. 881-893. Do jego koncepcji marginalności etnicznej i człowieka marginalnego (marginesu) nawiązuje m.in. Krzysztof Kwaśniewski; K. Kwaśniewski, Marginalność etniczna i narodowa, „Sprawy Narodowościowe", t. 16-17, 2000, s. 7-28.

${ }^{12} \mathrm{Z}$ terminem tym zetknęłam się podczas badań, jakie przeprowadziłam w obwodzie lwowskim (powiat starosamborski i turkiński), Stanowiły one część projektu badawczego, zatytułowanego „Polskie dziedzictwo kulturowe w nowej Europie” (PBZ-KBN-085/H01 -2002; III. C. 5).

${ }^{13}$ E. Smułkowa, dz. cyt., s. 7.

14 T. Ivanova, $d z$. cyt., s. 228.

15 Tacjana Ivanova zauważa, że we wschodniej części kraju, ze względu na stosunkowo małe zróżnicowanie religijne mieszkańców tych obszarów, pomieszanie widoczne jest przede wszystkim w sferze językowej, w części zachodniej natomiast obejmuje ono również wyznanie; T. Ivanova, $d z$. cyt., s. 225.

${ }^{16} 0$ występowaniu terminu pomieszany świat w odniesieniu do zmian wspomina również D. Życzyńska-Ciołek, dz. cyt., s. 203. Prezentując wyniki badań, przeprowadzonych na Grodzieńszczyźnie, skoncentrowała się ona jednak przede wszystkim na funkcjonowaniu wspomnianego terminu w opisach znanych jej rozmówcom przestrzeni zamieszkałych przez różne grupy etniczno-kulturowe. 
dem jest wojna, transformacja ustrojowa, „przesunięcie” granic, utrata domu rodzinnego. Określenie pomieszany świat oznacza ponadto sytuację zawieszenia między przeszłością a teraźniejszością, specyficzne poczucie egzystowania $\mathrm{w}$ dwóch światach. $\mathrm{W}$ tym sensie o pomieszanym świecie mówiły np. osoby, które przeżyły wojnę, przymusową zmianę miejsca zamieszkania, musiały też przystosować się do życia w nowym dla nich systemie $^{17}$. Wspominając wojnę i okres powojenny, moi rozmówcy mówili np.: „wszystko [zostało] przemieszane, przeplatane ${ }^{18}$; wszystko (...) przemieszane, połamane, pokręcone"19. Indywidualnych gospodarzy, pracujących na własnej ziemi, zastąpiły kołchozy, głębokie życie religijne miało zostać wyparte przez ateizację, osłabieniu uległy silne niegdyś więzi rodzinne i sąsiedzkie, coraz częstsze były konflikty (etniczne, religijne), zaczęły zanikać dawne wzory zachowań.

Mogłoby się wydawać, że w wyniku powojennych zmian nastąpił „ko[niec] świata gospodarzy i począt[ek] świata kołchoźników"20, że można mówić o „końcu świata panów” ${ }^{21}$, „końcu starego świata” ${ }^{22}$, ,»[a]bsolutna destrukcja starego systemu nie jest [jednak] w praktyce możliwa (...)«"23. Dawny świat przypominają np. ocalone od całkowitego zniszczenia budynki, wzniesione w czasach poprzedzających gwałtowne zmiany, wpisane w nowy krajobraz kulturowy, nierzadko pełniące inne funkcje ${ }^{24}$. Cząstka dawnego świata jest obecna w ludzkiej pamięci, w narracjach biograficznych poszczególnych osób, w zwyczajach rodzinnych, religijnych. Wspomnienia wywołują emocje, wiele osób ma poczucie krzywdy, tęskni za dawnym porządkiem ${ }^{25}$. 0 tym,

${ }^{17} \mathrm{O}$ zjawisku tym pisze również Lech Mróz, na przykładzie Litewskiej Socjalistycznej Republiki Radzieckiej. Podkreśla on, że jeden z tych światów „przetrwał w świadomości ludzi starszych, w ich opowieściach, pieśniach, zwyczajach, języku i określał myślenie i postępowanie w kręgu domowo-rodzinnym”, drugi "obowiązywał na zewnątrz, w miejscu pracy, miejscach publicznych, urzędach, szkole”; L. Mróz, Syndrom pogranicza. Uwagi na temat badań świadomości etnicznej, „Polska Sztuka Ludowa. Konteksty” 1993, nr 3-4, s. 53. Służyła mu indoktrynacja, narzucenie określonego modelu wychowania dzieci i młodzieży, propagowanie nowych wzorów postępowania (tamże).

${ }_{18}$ Kobieta, lat 70, Derewna (rej. stołpecki).

19 Kobieta, lat 88, Naliboki (rej. stołpecki).

20 A. Engelking, dz. cyt., s. 100.

21 Tamże, s. 157.

22 Tamże, s. 101.

${ }^{23}$ Tamże, s. 160. Na ten temat patrz też: L. Mróz, Syndrom pogranicza...

${ }^{24}$ A. Engelking, dz. cyt., s. 156-163.

25 Tamże; por. I. Kabzińska, Wśród „kościelnych Polaków”..., s. 175-177; Tejże, O słowach, emocjach i „polskiej krzywdzie”, „Etnografia Polska” 1999, z. 1-2, s. 81-100. 
że nie może być mowy o „absolutnej destrukcji starego systemu” świadczą liczne „analogie między systemem kołchozowym a folwarczno-pańszczyźnianym", wskazane przez Annę Engelking na podstawie przeprowadzonych przez nią badań ${ }^{26}$. Jej rozmówcy, mieszkańcy białoruskich wiosek, mówili m.in. o współczesnej pańszczyźnie, ciężkiej pracy od rana do wieczora, bez zapłaty lub słabo wynagradzanej (miało to miejsce zwłaszcza w początkowym okresie funkcjonowania gospodarki kołchozowej na terenach Białorusi), o zastąpieniu dawnych panów przez nowych, pełniących kierownicze funkcje w kołchozie. Można też mówić o podobieństwie wielu cech przypisywanych „starym” i „nowym” panom. A. Engelking podkreśla, że kołchoźnicy, podobnie jak ubodzy chłopi w okresie przedwojennym, pozostają na dole drabiny społecznej; ich kultura przeciwstawiana jest (także przez nich samych) kulturze wysokiej, pańskiej, szlacheckiej ${ }^{27}$. Zauważa też, że

[k]ołchoźnicza opowieść o kolektywizacji to przede wszystkim historia walki o życie i przeżycie. Można ją czy tać wręcz jako pean na cześć życia, głoszący chłopską dumę z tego, że - choć wydawało się to niemożliwe - lokalnym społecznościom udało się jednak przetrwać $(\ldots)^{28}$.

Zdaniem wspomnianej badaczki narracje kołchoźników, mówiące o gwałtownych zmianach, stanowiących zagrożenie dla trwałości grupy, jej egzystencji, w sensie fizycznym i kulturowym, wpisują się „, mityczny wzór chłopskiego myślenia w kategorii końca świata i jego nowego początku, wzór "przemiany światów«"29. A. Engelking przypomina też, że „badacze społeczni interpretują takie przemiany jako dezintegrację (destrukcję) wartości, norm i praktyki społecznej; z czasem pociąga ona za sobą procesy reintegracji (rekonstrukcji)"30 ${ }^{\prime 2}$ Chciałabym zauważyć, że koncepcja

${ }^{26}$ A. Engelking, dz. cyt., s. 162.

27 Tamże, s. 191-436.

${ }^{28}$ Tamże, s. 102; patrz też: tamże, s. 197-108,112-113, 157. W przejmujący sposób o afirmacji życia, wbrew dramatycznym doświadczeniom, mówią - moim zdaniem - bohaterowie książki Swietlany Aleksijewicz, Czarnobylska modlitwa. Kronika przyszłości, Wydawnictwo Czarne, Wołowiec 2012. Są to ludzie, którzy przeżyli awarię reaktora w Czarnobylu, wrócili do swojej wioski i komentują rzeczywistość, w której żyją. Wracają też wspomnieniami do czarnobylskiei katastrofy, mówiąc o jej tragicznych skutkach. Fragmenty tekstu Aleksijewicz zostały przeniesione na scenę warszawskiego Teatru Studio przez Joannę Szczepkowską. Premiera odbyła się 8 marca $2013 \mathrm{r}$.

${ }^{29}$ A. Engelking, dz. cyt., s. 101. Badaczka powołuje się na: M. Zowczak, Biblia ludowa. Interpretacje wątków biblijnych $w$ kulturze ludowej, Fundacja na Rzecz Nauki Polskiej, Warszawa 2000, s. 88-93. Podczas moich badań nie zetknęłam się z tym określeniem.

${ }^{30}$ A. Engelking, dz. cyt., s. 101. 
przemiany światów, znana m.in. Słowianom i Bałtom, odnosi się do definitywnego końca jednego świata i zastąpienia go innym. Przemiana światów dokonuje się najczęściej na skutek kataklizmów (potop, zaraza). Wyznaczają one wyraźną granicę/cezurę między światem dawnym i nowym. Zmiany mają charakter nieodwracalny. Moim zdaniem, bliższy rzeczywistości opisanej przez A. Engelking, na podstawie przeprowadzonych przez nią rozmów, jest termin pomieszany świat. Uwzględnia on zarówno gwałtowne zmiany, jak i życie między przeszłością a współczesnością (tego elementu, jak mi się wydaje, brak w przypadku przemiany światów).

Mieszkańcy Białorusi, i innych byłych republik radzieckich, doświadczają obecnie kolejnego pomieszania świata. Rozpoczęło się ono w schyłkowym okresie istnienia Związku Socjalistycznych Republik Radzieckich i trwa do dziś, w nowych realiach geo-politycznych i ustrojowych. Dla wielu osób, zwłaszcza starszych, traumatycznym przeżyciem jest rozpad ZSRR, przekształcenie poszczególnych republik w odrębne państwa oraz doświadczenie reform systemowych. W odniesieniu do współczesności, podobnie jak np. w stosunku do okresu powojennego, można mówić o współwystępowaniu elementów charakterystycznych dla starego i nowego porządku. Pojawia się tu również zjawisko, jakim jest tęsknota za idealizowaną przeszłością. Dzisiejsi mieszkańcy Białorusi tęsknią przede wszystkim za socjalistycznym państwem opiekuńczym. Co ciekawe, zjawisko polegające na idealizowaniu przeszłości występuje nie tylko wśród osób należących do starszego i średniego pokolenia, ale niekiedy również wśród ludzi młodych, nie znających realiów minionego systemu z bezpośrednich doświadczeń, lecz jedynie z przekazanych im wspomnień rodziców i dziadków.

\section{Biblijna opowieść o wieży Babel: Pra-źródło „pomieszanego świata”}

Pytani o źródła różnic kulturowych, językowych, religijnych, a więc o genezę pomieszanego świata, mieszkańcy Białorusi najczęściej odwołują się do biblijnej opowieści o wieży Babel ${ }^{31}$. Opowieść ta znana jest również na Wileńszczyźnie ${ }^{32}$. Niewiele osób czytało stosowny fragment Księgi Rodzaju.

31 Patrz np.: Tamże, s. 265-267, 620-650; D. Życzyńska-Ciołek, dz. cyt., s. 205-206.

32 Patrz np.: J. Straczuk, Język a tożsamość człowieka w warunkach społecznej wielojęzyczności. Pogranicze polsko-litewsko-bialoruskie, Wydawnictwa UW, Warszawa 1999; M. Zowczak, dz. cyt., s. 182-205; D. Życzyńska-Ciołek, dz. cyt., s. 205-206. 
Rozmówcy najczęściej powołują się na przekazy ustne - informacje podane przez duchowieństwo, nauczycieli w przedwojennej szkole, ludzi starych (rodzinę, sąsiadów). Opierają się też na publikacjach proroctw królowej Saby, zwanej też Sybillą lub Micheldą, a ściślej - którejś z ich licznych wersji.

Księga Rodzaju mówi, że mieszkańcy ziemi posługiwali się początkowo jednym językiem ${ }^{33}$. Wędrując ze wschodu, dotarli do kraju Szinear. Tam zapragnęli zbudować miasto i wieżę sięgającą wierzchołkiem do nieba, Pan Bóg jednak nie dopuścił do realizacji tego zamiaru. „Pomieszał” im język i odtąd nie mogli się ze sobą porozumiećc ${ }^{34}$.

(...) Pan zstąpił z nieba, by zobaczyć to miasto i wieżę, które budowali ludzie, i rzekł: „Są oni jednym ludem i wszyscy mają jedną mowę, i to jest przyczyną, że zaczęli budować. A zatem w przyszłości nic nie będzie dla nich niemożliwe, cokolwiek zamierzą uczynić. Zejdźmy więc i pomieszajmy tam ich język, aby jeden nie rozumiał drugiego" ${ }^{\prime \prime}$.

Miejsce, w którym miała stanąć wieża, „nazwano (...) Babel, tam bowiem Pan pomieszał mowę mieszkańców całej ziemi (...)”36. Zauważmy, że w Księdze Rodzaju jest mowa o „pomieszaniu” języka, którym posługiwali się budowniczowie wieży, ludowe interpretacje biblijnej opowieści mówią natomiast najczęściej o „pomieszaniu języków”37. Działanie Boga interpretowane jest jako kara wymierzona tym, którzy, kierując się pychą, pragnęli wznieść wieżę sięgającą nieba, by pokazać, że są równi Bogu ${ }^{38}$. Myślenie to jest zgodne z treścią komentarza, jakim w Piśmie Świętym opatrzono opowieść o wieży Babel:

Folklorystyczne to opowiadanie ma wyjaśnić przyczynę różnorodności narodów i języków. Oto ludzkość po potopie oddala się coraz bardziej od Boga, dążąc do przekroczenia granic jej zakreślonych. Gigantyczna budowla jest ucieleśnieniem tych niezdrowych dążeń. (...) Karą za rosnącą pychę jest rosnące niezrozumienie między narodami $(. . .)^{39}$.

${ }^{33}$ Według rozmówców A. Engelking był to „język żydowski”; A. Engelking, dz. cyt., s. 634-635.

${ }^{34}$ Księga Rodzaju (Rdz) 11, 1-9.

$35 \mathrm{Rdz} 11,5-7$.

${ }^{36}$ Tamże; por. wyjaśnienie: „Babel = balal (pomieszał)”, Pismo Święte Starego i Nowego Testamentu. Biblia Tysiąclecia, pod red. ks. K. Dynarskiego, Wydawnictwo Pallotinum, Poznań -Warszawa 1998, przypis do Księgi Rodzaju 11, 9, s. 32.

${ }^{37}$ Patrz np.: A. Engelking, dz. cyt., s. 266, 621, 635.

${ }^{38}$ M. Zowczak, dz. cyt., s. 190-191; D. Życzyńska-Ciołek, dz. cyt., s. 206.

39 Pismo Święte..., s. 32, przyp. 11, 1. 
Anna Engelking kilkakrotnie pisze o upadku wieży Babel ${ }^{40}$, w cytowanych przez nią przykładowo wypowiedziach białoruskich rozmówców nie ma jednak o tym mowy ${ }^{41}$ (mówią oni jedynie o „pomieszaniu języków”). Motyw zburzenia wieży pojawia się natomiast w wersji odnotowanej na Wileńszczyźnie ${ }^{42}$.

W niektórych ludowych wariantach opowieści wymieniona jest liczba budowniczych wieży Babel i tożsama z nią liczba języków, które powstały w wyniku Boskiej interwencji i „pomieszania” pierwotnej, wspólnej wszystkim mowy. Na przykład w wariancie zarejestrowanym na Wileńszczyźnie przez Magdalenę Zowczak pojawia się informacja o siedemdziesięciu dziewięciu językach i takiej samej liczbie budowniczych ${ }^{43}$. Mieszkańcy białoruskich wiosek, z którymi rozmawiała A. Engelking, mówili o siedemdziesięciu językach ${ }^{44}$. Badaczka zauważa, że taka sama liczba języków występuje w legendach żydowskich ${ }^{45}$. W innych źródłach pojawiają się wzmianki o siedemdziesięciu dwóch językach: „»Pisarze wczesnochrześcijańscy (...) wyprowadzili różnorodność języków z legendy o wieży Babel i starali się ułożyć tabelę 72 ludów i języków «"46. Stanisław Bylina przypomina, że Kosmas „rozpoczyna swój wykład dziejów czeskich od wieży Babel, spod której rozeszli się po świecie protoplaści 72 ludów"47. Dodaje też, że

niepodważalny, gdyż objawiony tekst Pisma Świętego nic wprawdzie bezpośrednio nie mówił o dziejach plemienia słowiańskiego, lecz systematyzował pierwotne losy ludzkości, ustalając układ wyjściowy i kierunki późniejszych przeobrażeń. W kronikarstwie zachodniosłowiańskim ten kierunek refleksji historycznej zainicjował [właśnie wspomniany wcześniej] Kosmas (... $)^{48}$.

${ }^{40}$ A. Engelking, dz. cyt., s. 620, 625, 634, 640, 649. Za swoimi rozmówcami A. Engelking mówi również o „miesza[niu] język[ów] budowniczym wieży” (tamże, s. 649, przyp. 84).

${ }^{41} \mathrm{O}$ upadku wieży Babel nie wspomina również znany mi tekst Księgi Rodzaju.

${ }^{42}$ M. Zowczak, dz. cyt., s. 191-192.

43 Tamże, s. 191.

${ }^{44}$ A. Engelking, dz. cyt., s. 649.

45 Tamże, s. 649, przyp. 84; A. Engelking powołuje się na: M. J. Bin Gorion, Żydowskie legendy biblijne, tłum. i opr. R. Stiller, Wydawnictwo KOS, Katowice 2009, s. 122-124.

${ }^{46}$ B. Zientara, Świt narodów europejskich. Powstawanie świadomości narodowej na obszarze Europy pokarolińskiej, PIW, Warszawa 1985, s. 22; cyt. za: A. Engelking, dz. cyt., s. 649, przyp. 84.

${ }^{47}$ S. Bylina, Motyw jedności słowiańskiej w Polsce późnego średniowiecza. [w:] Słowianie, Słowiańszczyzna - pojęcia i rzeczywistość, pod red. K. Handke, Fundacja Slawistyczna, Instytut Slawistyki Polskiej Akademii Nauk, Warszawa 2002, s. 47.

${ }^{48}$ Tamże. 
W Księdze Rodzaju jest mowa o przyczynach pojawienia się różnych języków, ludowe interpretacje, np. te zarejestrowane przez badaczy na Białorusi i Litwie, idą jednak dalej. Mówią o powstaniu różnorodnych kultur, narodów, państw, religii ${ }^{49}$. Takie myślenie ma swoje uzasadnienie i analogie m.in. w „najdawniejszych zabytkach piśmiennictwa ruskiego” ${ }^{50}$. Występujący w nich „termin jazyk jest odpowiednikiem greckiego ethnos i zarazem synonimem wyrazów ziemla, strana i rod. Jazyk w tamtej epoce, oprócz 'mowy' oznaczał 'społeczeństwo, plemię, naród', a przede wszystkim miał znaczenie kościelno-religijne - »jazyk to metropolia kościelna zarówno w sensie administracyjno-terytorialnym jak i ludności osiadłej na danym terytorium «"51. Także B. Zientara podkreśla, że

[b]iblijna opowieść o budowie wieży Babel, której twórcy chcieli sięgnąć nieba, stworzyła możliwość wyjaśnienia różnic między społeczeństwami ludzkimi. Obliczono, że rozpędzając ludzi na wszystkie strony świata, Bóg dał im siedemdziesiąt dwa języki; z tych siedemdziesięciu dwóch wspólnot językowych powstały później liczniejsze jeszcze narody - gentes lub nationes; każdy żyjący osobno i nierozumiejący innych $^{52}$.

\section{Justyna Straczuk zauważa, że}

[o]d czasów wieży Babel każda nacja swoju wieru ma, co oznacza, że każda nacja modli się po swojemu. Różnorodność wiar, narodów i języków jest więc wpisana w kosmologię: wszechświat zbudowany jest z klocków - rozmaitych grup ludzkich, które składają się na jego całośćs3.

Porównanie do klocków, aczkolwiek obrazowe, nie wydaje mi się trafne. W tym przypadku bowiem trudno mówić o przekraczaniu granic, mieszaniu, w którego efekcie powstają zjawiska specyficzne dla kultury pogranicza, np. mieszany język, mieszana krew, małżeństwa mieszane, złożona tożsamość.

„Porząd[ek] zwany pomieszaniem opiera się na następujących zasadach”: „Każdy człowiek powinien wierzyć w Boga”, „w każdej nacji są ludzie dobrzy

${ }^{49}$ Więcej na ten temat patrz: A. Engelking, dz. cyt., s. 265-267, 620-650; patrz też: J. Straczuk, dz. cyt., s. 38-40; M. Zowczak, dz. cyt., s. 183-205.

${ }^{50}$ H. Paszkiewicz, Powstanie narodu ruskiego, opr. L. Korczak, PAU, Kraków 1998, s. 53; cyt. za: A. Engelking, dz. cyt., s. 642. Autorka przytacza ten cytat za: W. Pawluczuk, Światopogląd jednostki w warunkach rozpadu społeczności tradycyjnej, PWN, Warszawa 1972, s. 226.

${ }^{51}$ Tamże.

52 B. Zientara, $d z$. cyt., s. 22; cyt. za: A. Engelking, dz. cyt., s. 649, przyp. 84.

${ }^{53}$ J. Straczuk $d z$. cyt., s. 45. 
i źli”, „Pan Bóg jest jeden, choć wiar na świecie dużo”, „każdy powinien trzymać się ${ }^{54}$ swojej wiary"55. Poza tym porządkiem, stworzonym przez Boga, pozostają ci, którzy odrzucają jakąkolwiek religię ${ }^{56}$. W porządku odpowiadających sobie wiar, języków i nacji ${ }^{57}$ nie mieści się język prosty (miaszanaja mowa), którym posługują się mieszkańcy białoruskich wiosek. Nie ma on odpowiednika w żadnej z religii ${ }^{58}$. „Mowa prosta nie ma sakralnej genezy, nie pochodzi od Boga. Nie należy do tego ustanowionego przez mit porządku ludzkości podzielonej na nacje, czyli wiary konstytuowane przez języki”59. „Jest to język codziennej rozmowy, używany w domu i we wsi, a nie w świątyni czy w modlitwie. Ani w cerkwi, ani w kościele nikt nie modli się po prostu [w języku prostym - dop. I. K.]. Nie ma książeczek do nabożeństwa pisanych językiem prostym. Nie ma wiary prostej, a jest język prosty (...)"60. Danuta Życzyńska-Ciołek zaznacza, że „[t]o nie jest tak naprawdę język tylko zwyczajna mowa służąca porozumieniu ludzi różnej nacji. Narzędzie komunikacji, i nic więcej"61. Nie deprecjonowałabym jednak tego języka, nawet jeśli czynią tak jego użytkownicy, ma on bowiem ogromne znaczenie dla mieszkańców pomieszanego świata. Dzięki niemu mogą się ze sobą komunikować, podejmować wspólne działania, tworzyć lokalne wspólnoty. W innej sytuacji, zauważmy, znajdowali się budowniczowie wieży Babel, którzy na skutek Boskiej interwencji - nie potrafili się już ze sobą porozumieć, nie dokończyli też wznoszonej przez siebie budowli.

Niektórzy rozmówcy A. Engelking uważali, że byłoby dobrze, gdybyludzie na całym świecie mówili jednym, zrozumiałym dla wszystkich językiem ${ }^{62}$. Jeśli by tak się stało, wrócilibyśmy do sytuacji sprzed „pomieszania” języka

${ }^{54}$ To znaczy nie powinien jej zmieniać - dop. I. K.

55 D. Życzyńska-Ciołek, dz. cyt., s. 203-204.

56 A. Engelking, dz. cyt., s. 756; patrz też: Tamże, s. 622, 624.

57 Terminem nacje mieszkańcy Białorusi określają wiary i języki, te ostatnie są często utożsamiane z narodami; nacje utożsamiane są też z państwami; A. Engelking, dz. cyt., s. 267. W języku rosyjskim słowo нация oznacza narodowość, naród, a także „wspólnotę terytorialną, językową i kulturową, charakteryzującą się obecnością samoświadomości etnicznej jej członków"; И. И. Ковкел, История Беларуси, Гродна 1997, s. 59-60.

${ }^{58}$ D. Życzyńska-Ciołek, dz. cyt., s. 205-206; A. Engelking, dz. cyt., s. 267-270.

59 A. Engelking, dz. cyt., s. 267.

${ }^{60}$ D. Życzyńska-Ciołek, dz. cyt., s. 205-206.

61 Tamże, s. 206.

${ }^{62}$ A. Engelking, dz. cyt., s. 650. Jako pozytywny przykład podawano Związek Radziecki, w którym językiem komunikacji przedstawicieli różnych grup etnicznych był rosyjski (Tamże). 
używanego przez budowniczych wieży Babel, nie byłby to jednak zapewne ten sam język. Swoich zwolenników ma również wizja świata, w którym istniałaby jedna religia. Grupę tę reprezentuje jedna z moich rozmówczyń ${ }^{63}$. $Z$ jej wypowiedzi jasno wynika, że realizacja tej idei nie jest możliwa, istnienie wielu religii jest bowiem zgodne z wolą Boga. Wielość wyznań sprzyja jednak - zdaniem tej kobiety - konfliktom na tle religijnym, wywołuje nienawiść. Ta sama kobieta powiedziała, że gdyby Pan Bóg chciał, by ludzie byli równi, to by ich takimi stworzył. Stworzyłby też drzewa w lesie równej wielkości, takie same krzaki, mchy i trawy. Nie uczynił jednak tego, ludzie różnią się więc między sobą, np. wyglądem i pozycją społeczną, istnieje też wiele kultur, religii, języków. Różnice między ludźmi i ich konsekwencje można, jak widać, uznać za część Bożego planu. Idąc dalej, można przyjąć, że częścią tego planu jest istnienie pomieszanego świata, usankcjonowanie różnic kulturowych. Wskazuje na to biblijna opowieść o wieży Babel, „afirmują[ca] (...) kulturową różnorodność i uzasadnia[jąca] genealogię oraz trwanie zróżnicowanej religijnie społeczności"64.

Zdecydowana większości rozmówców A. Engelking twierdziła, że wiary są sobie równe, nie ma wyznań lepszych i gorszych ${ }^{65}$. Podkreślano też, że ludzie religijni, niezależnie od identyfikacji z określona konfesją, wierzą w tego samego Boga. Z podobnymi wypowiedziami zetknęłam się podczas swoich badań. Moi rozmówcy natomiast wartościowali kultury. Kulturę polską stawiano wyżej niż rosyjską i białoruską. Klasyfikacja oparta była na obserwacjach codziennych zachowań przedstawicieli poszczególnych grup. Złożyły się one na stereotypowy obraz „swoich” i „innych”, pozwalały też na skonstruowanie opozycji, w których ważne miejsce zajmował np. stosunek do drugiego człowieka, grzeczność, uprzejmość, wygląd zewnętrzny, przestrzeganie porządku, troska o estetyczne podanie i smak potraw, posługiwanie się poprawnym językiem ${ }^{66}$. Niektórzy mieszkańcy pogranicza białorusko-litewskiego wyżej od kultury polskiej klasyfikowali kulturę litewską. 0 jej wyższości, ich zdaniem, zadecydował szybki rozwój ekonomiczny Litwy oraz czystość i porządek panujące w litewskich domach i gospodarstwach.

\footnotetext{
${ }^{63}$ Kobieta, lat 77, Naliboki.

${ }^{64}$ A. Engelking, dz. cyt., s. 650.

${ }^{65}$ Tamże, s. 627-641.

${ }^{66}$ Więcej patrz: I. Kabzińska, Wśród „kościelnych Polaków”..., s. 48, 115-118.
} 
W pomieszanym świecie istnieją nie tylko lepsze i gorsze kultury. Występują tu również, jak już wspomniałam, lepsze („czyste”, ,kulturalne”) i gorsze języki. Do tej kategorii należy język prosty (mjaszanaja mowa), sytuowany na dole językowej hierarchii ${ }^{67}$.

\section{„Planeta nomadów”68}

W ludowych interpretacjach opowieści o wieży Babel akcent położony jest na pomieszanie, w którego wyniku powstało wiele języków, kultur, wiar, państw i narodów. Stanowią one podstawowe składniki pomieszanego świata. Mniej uwagi poświęca się innemu czynnikowi, równie ważnemu dla powstania tego zjawiska, jakim są migracje ${ }^{69}$. Biblijna opowieść mówi o tym, że budowniczowie wieży Babel byli wędrowcami, którzy przybyli ze wschodu do kraju Szinear, gdzie zapragnęli się osiedlić. Nie udało im się to jednak, Bóg bowiem nie tylko „pomieszał” im język, lecz także skazał ich na dalszą wędrówkę: „Pan rozproszył ich stamtąd po całej powierzchni ziemi"70. Wspomniana opowieść wskazuje więc także pra-źródło migracji.

O związku między migracjami (w różnej skali) i pomieszaniem świata mówili moi rozmówcy. Jako przykład podawano powojenne zmiany składu etnicznego i społecznego wielu miejscowości. Bez względu na swą przynależność etniczną i miejsce pochodzenia (może nim być nawet sąsiednia wioska), przybysze do dziś określani są przez autochtonów mianem „obcych” lub „przybłędów”. Inną, wspomnianą przez rozmówców, grupę przymusowych wędrowców, żyjących w pomieszanym świecie, stanowią ci, którzy po wojnie wyjechali do Polski w ramach tzw. repatriacji. Kolejną grupę tworzą osoby, które w czasie II wojny światowej, wraz z armią generała

${ }^{67}$ Biblijna opowieść o wieży Babel inspirowała wielu twórców (malarzy, pisarzy, autorów scenariuszy filmowych, reżyserów). Niezwykle ciekawą analizę wybranych dzieł nawiązujących do tego motywu przedstawiła Patrycja Cembrzyńska w książce Wieża Babel. Nowoczesny projekt porządkowania świata i jego dekonstrukcja, Universitas, Kraków 2012. Z książką tą zapoznałam się po oddaniu prezentowanego tu tekstu do Wydawnictwa, nie nawiązuję więc do niej w swoim tekście.

${ }^{68}$ Określenie to zapożyczyłam od Karla Schlögla; K. Schlögel, Środek leży na wschodzie. Europa w stadium przejściowym, tłum. A. Kopacki, Oficyna Naukowa, Warszawa 2005, s. 74-141.

${ }^{69}$ Zdaniem K. Kwaśniewskiego, „[p]omieszanie wynika zwykle [m.in.] z różnego rodzaju migracji i najazdów”; K. Kwaśniewski, dz. cyt., s. 24, patrz też: I. Kabzińska, „Pomieszany świat"..., s. 28-37.

${ }^{70} \mathrm{Rdz} 11,8$. 
Władysława Andersa, dotarły na Bliski Wschód, a następnie - do USA lub Kanady. Kilka osób reprezentujących tę grupę, z którymi miałam okazję rozmawiać, posłużyło się terminem pomieszany świat, opowiadając o swym życiu i poczuciu zawieszenia między światem sprzed wojny i tym powojennym, w którym wciąż czują się jak przymusowi emigranci i którego, mimo upływu wielu lat, nie zdołały całkowicie zaakceptować71.

Biblijna opowieść o wieży Babel nie mówi o losach wędrowców zmuszonych przez Boga do opuszczenia kraju Schinear. Dzięki ludowym wersjom, zanotowanym m.in. na Litwie i Białorusi, jak też komentarzom badaczy ${ }^{72}$, możemy dopowiedzieć, że dali oni początek różnym nacjom (religiom, kulturom, państwom). Stworzyli też wielokulturowe społeczności ${ }^{73}$. Historia ludzkości, w której migracje zajmują poczesne miejsce, świadczy o tym, że potomkowie budowniczych wieży Babel podzielili losy swych przodków, stając się, jak oni, emigrantami (bardzo często - przymusowymi) ${ }^{74}$.

„Ludzie wędrowali od początku dziejów”75, zmienia się jednak skala migracji, ich charakter, kierunki, sposób organizacji. Różne są też ich przyczyny. Należą do nich np.: bezrobocie, ubóstwo, wojna, różnego rodzaju konflikty (m.in. etniczne, religijne) przeludnienie, brak podstawowej opieki medycznej, niedostatki w systemie edukacji, brak poczucia bezpieczeństwa, przemoc, korupcja, łamanie praw człowieka, dyskryminacja wynikająca ze

${ }^{71} \mathrm{Z}$ osobami tymi rozmawiałam latem 1994 r. podczas ich i mojego pobytu na Białorusi. Przyjechały one na uroczystość konsekracji parafialnego kościoła we wsi Naliboki (rej. stołpecki).

${ }^{72}$ Patrz np. B. Zientara, dz. cyt., s. 22.

${ }^{73}$ K. Schlögel zauważył, że „[w]ielokulturowość, o której [tak często - dop. I. K.] dyskutuje się dzisiaj, już kiedyś istniała - w Konstantynopolu, Aleksandrii, Sankt Petersburgu, Łodzi, Czerniowcach i gdzie indziej, Padła [jednak] ofiarą czystek"; K. Schlögel, dz. cyt., s. 110.

${ }^{74}$ Dalsza część tekstu, w częściowo zmienionej formie, została opublikowana w: I. Kabzińska, Mały kraj masowej emigracji (Republika Litewska), [w:] Zawstydzona mądrość. Prace ofiarowane Ojcu Profesorowi Franciszkowi Rosińskiemu OFM, pod red. Małgorzaty Łoboz i Alana Tomasza Brzyskiego OFM, Franciszkańskie Wydawnictwo św. Antoniego, Wrocław 2013. Prezentowany tu tekst uzupełniłam m.in. o najnowsze dane statystyczne dotyczące emigracji z Litwy.

${ }^{75}$ A. Walaszek, Migracje Europejczyków 1650-1914, Wydawnictwo Uniwersytetu Jagiellońskiego, Kraków 2007, s. 18; na temat migracji patrz też np.: The Age of Migration: International Population Movement in the Modern World, pod red. S. Castles, M. Miller, The Guilford Press, New York 1993; L. Page Moch, Moving Europeans: Migration in Western Europe since 1650, Indiana University Press, Bloomington 1992; J. Salt, Current Trends in International Migration in Europe, Council of Europe, Strasbourg 1997; Ch. Tilly, Human Migration: Patterns and Politics, Indiana University Press, Bloomington 1978. 
względów społecznych, etnicznych i/lub religijnych ${ }^{76}$. Część osób jednak, jak wiadomo, emigruje dobrowolnie, kierując się np. ciekawością, chęcią własnego rozwoju, poprawy warunków życia, względami rodzinnymi (małżeństwo z cudzoziemcem, łączenie rodzin).

Żyjemy na „planecie nomadów” - pisze Karl Schlögel. „Niemal każdy miał już (...) do czynienia" ze zjawiskiem, które

ma wiele imion, zależnie od okoliczności: robotnik wędrowny, obcy, cudzoziemiec, gastarbeiter, współobywatel-obcokrajowiec, uciekinier, ubiegający się o azyl, azylant, displaced person, bezpaństwowiec, transnational, apatryda, undocumented lub non-documentado, egzul, migrant, emigrant, imigrant. Ostatecznie jednak wszystko to są imiona postaci prastarej, archaicznej - postaci nomady ${ }^{77}$.

Schlögel zauważa, że dla współczesnego świata „idea osiadłości przestała być czymś oczywistym”78. Powinniśmy, jego zdaniem, pytać „nie tylko, dlaczego tak wielu ludzi decyduje się na wędrówkę, lecz także, dlaczego ludzie zostają na miejscu, choć istnieje mnóstwo powodów, by je opuścić (....”79. Myślę, że należałoby też zapytać, jaką cenę płacą migranci za swoje - nie zawsze dobrowolne - decyzje. Jakie koszty ponoszą ich najbliżsi i społeczeństwa, z których się wywodzą? Jakie zjawiska związane z migracją można uznać za pozytywne? Jakie są ich negatywne następstwa?

Migranci mają znaczący udział w tworzeniu wielokulturowych społeczeństw, pograniczy kulturowych, międzykulturowych przestrzeni. Proces ten będzie się pogłębiał. Przewiduje się, że w najbliższych dziesięcioleciach co dziesiąty mieszkaniec Europy będzie imigrantem albo potomkiem imigrantów ${ }^{80}$. Około 2050 roku na jednego mieszkańca Europy przypadnie 3 imigrantów z Afryki ${ }^{81}$. W końcu obecnego stulecia „wkład” imigrantów

${ }^{76}$ Czynniki te są najczęściej wymieniane wśród przyczyn migracji; patrz np.: A. Grynia, Międzynarodowa migracja mieszkańców Litwy: Stan obecny i prognozy na przyszłość, „Rocznik Stowarzyszenia Naukowców Polaków Litwy", t. 6, 2007, s. 30.

77 K. Schlögel, dz. cyt., s. 74.

78 Tamże, s. 83.

79 Tamże. Autor pisze też o „społeczeństwa[ch] na lotnych piaskach” i o powszechnym ruchu (podrozdział zatytułowany „Global flows. Wszystko płynie” (Tamże, s. 111-112).

${ }^{80}$ Р. П. Скорый, Основные направления иммиграционной политики стран Европейского Союза, [w:] Меняющаяся Европа. Проблемы этнокультурного взаимодействия, pod red. М. Ю. Мартыновой, Российская Академия Наук, Москва 2006, s. 14.

${ }^{81}$ Tamże, s. 18. 
w ogólny przyrost mieszkańców Europy będzie stanowił 75\% ${ }^{82}$. Oznacza to m.in. konieczność wypracowania polityki uwzględniającej wzrost liczby imigrantów, rozstrzygania licznych problemów związanych z ich integracją, zaspokojeniem potrzeb socjalnych, kulturalnych, ekonomicznych, zapewnieniem bezpieczeństwa, łagodzeniem podziałów „my” - „oni”83. Skala migracji z pewnością będzie rosła, zjawisko to jest bowiem uważane za „multinational billion-dollar-business (Myron Weiner), a zatem, podobnie jak handel narkotykami, prostytucja i handel bronią, stanowi część gospodarki światowej"84. Można przypuszczać, że jednym z następstw migracji będzie coraz większe pomieszanie świata.

W Europie osiedlają się liczni przybysze z Azji, Afryki, Ameryki Południowej, mamy jednak także do czynienia z migracjami w skali kontynentu. W wielu krajach zjawisko to przybrało niepokojące rozmiary. Jednym z takich krajów jest Litwa. Jej mieszkańcy, obok ludności Polski, należą do najbardziej mobilnych narodów Europy Środkowo-Wschodniej ${ }^{85}$. Według oficjalnych danych litewskiego Departamentu Statystyki, w latach 1990-2007 Litwę opuściło 182,5 tys. osób ${ }^{86}$, w 2008 wyemigrowało z niej 23,7 tys. osób, rok później - 34,7 tys. ${ }^{87}$ Według danych Międzynarodowej Organizacji ds. Migracji, w roku 2010 z Litwy wyjechało ponad 83,5 tys. osób, w roku 2011 - około 40 tys. ${ }^{88}$ Ogółem, według oficjalnych źródeł, w latach 1990-2011 z Litwy wyemigrowało 670 tys. osób ${ }^{89}$. „Litwa jest liderem wśród państw unijnych pod względem emigracji w przeliczeniu na 1000 mieszkańców kraju”90.

82 Tamże, s. 22.

83 Tamże, s. 12-14.

84 K. Schlögel, dz. cyt., s. 76.

85 A. Grynia, Międzynarodowa migracja..., s. 33. Autorka powołuje się m.in. na: http://www3, lrs.lt/pls/inter/w5_show?p_r (dostęp: 16.05.2008).

86 A. Grynia, Przegląd podstawowych korzyści i kosztów wynikających z przynależności Litwy do UE, „Rocznik Stowarzyszenia Naukowców Polaków Litwy”, t. 6, 2007, s. 12. Dane te pochodzą m. in. z: http://www. stat.gov.lt/lt/news/view/?id... (dostęp: 28.05.2008).

87 A. Grynia, Rynek pracy w dobie kryzysu: Litwa na tle Europy, [w:] Wpływ światowego kryzysu gospodarczego na kraje Europy Środkowej i Wschodniej. Aspekty gospodarcze i społeczne, pod. red. tejże, Uniwersytet w Białymstoku Filia w Wilnie, Centrum Doradztwa i Ekspertyz Gospodarczych, Warszawa-Wilno 2011, s. 70.

${ }^{88}$ Alarmujące dane dot. emigracji na Litwie; http://wiadomosci,onet.pl/swiat/alarmujace -dane-dot-emigracji-na-litwie... (dostęp: 05.02.2013).

89 G. Bolzane, „Litwa nie jest dobrym krajem do życia”; http://www.presseurop.eu/pl/content/article/1498561-litwa-nie-jest-dobrym-krajem... (dostęp: 05.02.2013).

90 Ten kraj UE pustoszeje. Rekordowa emigracja; http://www.sfora.pl/Ten-kraj-UE-pustoszeje-Rekordowa-emigracja (dostęp: 05.02.2013). 
Rzeczywista liczba emigrantów nie jest znana, wielu wyjeżdżających nie rejestruje się bowiem w urzędzie emigracyjnym. Można natomiast z pewnością powiedzieć, że „(...) skala emigracji jest bardzo wysoka” ${ }^{91}$. Należy też spodziewać się jej dalszego wzrostu. Chęć wyjazdu za granicę (na stałe) deklaruje ok. $60 \%$ młodzieży do 29 roku życia ${ }^{92}$. Z badań przeprowadzonych przez Instytut Faktus wynika, że 74\% laureatów olimpiad (litewskich i międzynarodowych) zamierza studiować za granicą ${ }^{93}$. Wielu z nich zapewne pozostanie tam na zawsze. Badania przeprowadzone na początku 2011 r. przez spółkę Prime Consulting wykazały, że z Litwy zamierza wyjechać jedna trzecia ludności dużych miast i jedna czwarta mieszkańców wsi ${ }^{94}$. Chęć emigracji zgłasza wielu lekarzy, informatyków, inżynierów, a także liczne osoby nie mające określonych kwalifikacji, bezskutecznie poszukujące pracy na Litwie ${ }^{95}$.

„W poszukiwaniu pracy za granicą mieszkańcy Litwy korzystają z pomocy nie tylko Litwinów, ale także Polaków i Rosjan, którzy już wyemigrowali. (...) uzyskują [także] pomoc na emigracji (...) za pośrednictwem Kościoła katolickiego" ${ }^{\prime 96}$. Nie wszyscy emigranci jednak realizują swoje marzenia. Doświadczenia niektórych spośród nich są dramatyczne pracują ponad siły, bez ubezpieczenia i umowy o pracę, są oszukiwani przez pracodawców, wyzyskiwani. Najczęściej nie znają języka obowiązującego w danym kraju, ani miejscowego prawa, zdani są więc wyłącznie na pośredników, wśród których są często osoby nieuczciwe, pozbawione skrupułów ${ }^{97}$. Autorka artykułu, na który się tu powołuję, konstatuje: „Smutne jest to, że często po wyjeździe do pracy Litwini wykorzystywani są nie tylko przez obcokrajowców, ale również przez rodaków"98.

${ }^{91}$ A. Grynia, Rynek pracy..., s. 70. patrz też J. Łuczyńska, Rynek pracy na Litwie po wejściu do Unii Europejskiej, „Rocznik Stowarzyszenia Naukowców Polaków Litwy” 2007, nr 6, s. 153.

${ }^{92}$ A. Akińczo, Rekordowa emigracja z Litwy; http://news.money.pl/artykul/rekordowa; emigracja; z; Litwy (dostęp: 05.02.2013).

93 Tamże.

${ }^{94}$ E. Szałkowska, Nadciaga nowa fala emigracji; http://kurierwilenski.lt/2011/01/10. nadciąga-nowa-fala-emigracji (dostęp: 05.02.2013).

95 Tamże.

${ }^{96}$ Alarmujące dane. Autorką cytowanej w tekście wypowiedzi jest szefowa wileńskiego biura Międzynarodowej Organizacji ds. Migracji, Audra Sipawicziene.

${ }^{97}$ K. Merska-Pietrak, Nikt się nie buntuje, „Angora” 20.01.2013, s. 81.

98 Tamże. 
Emigracja nie jest niczym nowym dla litewskiego społeczeństwa ${ }^{99}$, jej obecne rozmiary budzą jednak niepokój. Obawy o przyszłość kraju ilustrują wypowiedzi moich rozmówców: „U nas mówią, że Litwy nie będzie. Taka mała, trzy miliony ludzi, a tyle ludzi wyjechało”"100; „Oficjalnie z Litwy wyjechało do innych krajów trzysta tysięcy osób. Na trzy miliony ludności to bardzo dużo. A ile wyjechało nieoficjalnie? Kto to wie?"101. W wyniku emigracji pustoszeją litewskie miasta i wsie, pogłębia się też proces starzenia się społeczeństwa: „Młodzi wyjeżdżają. W lecie nie ma młodych na ulicach Wilna. Pracują na Zachodzie (w Niemczech, Szwecji, krajach Unii). To jest dla nich szansa, ale nie byłoby dobrze, żeby wyjechali na stałe. Na wsi sami starzy ludzie"102. Negatywnym skutkiem emigracji, na który wskazywało wiele osób, jest rozbicie rodzin. Podkreślano, że niezwykle trudna jest sytuacja dzieci, których rodzice (oboje lub jedno z nich) wyjechali „za chlebem” ${ }^{103}$.

Z przeprowadzonych przeze mnie rozmów wynika, że wzrastająca skala emigracji jest jednym z najważniejszych problemów litewskiego społeczeństwa ${ }^{104}$.Zdaniem rozmówców, zjawisko to ma najczęściej charakter przymusowy ${ }^{105}$. Jego przyczyną jest przede wszystkim bardzo wysokie bezrobocie oraz niskie płace, nie pozwalające na zaspokojenie podstawo-

${ }^{99} \mathrm{Na}$ ten temat patrz np. G. Bolzane, dz. cyt. Autor przypomina m. in., że w XVIII -XIX w. wielu Litwinów wyjechało do USA. Wyjazdy miały przede wszystkim charakter ekonomiczny.

100 Kobieta, lat 70, Druskienniki. Badania zostały przeprowadzone w latach 2004-2008. Były one częścią projektu „Polskie dziedzictwo kulturowe w nowej Europie” (PBZ-KBN-085 /H01/2002). Dotyczyły m. in. postaw wobec zmian systemowych, trwających od początku lat 1990., ich efektów, kosztów społecznych i doświadczeń związanych z transformacją. Wyniki badań prezentuję w książce: I. Kabzińska. Między pragnieniem ideału a rzeczywistościq̨. Polacy na Litwie, Białorusi i Ukrainie w okresie transformacji systemowej przełomu XX i XXI stulecia, Letter Quality, Warszawa 2009.

101 Kobieta, lat 68, Kowno.

102 Kobieta, lat 72, Wilno.

103 Patrz też: A. Grynia, Międzynarodowa migracja..., s. 41. Badaczka podkreśla, że „gdyby emigranci pracowali na Litwie, to płaciliby do budżetu państwa podatki i ubezpieczenia socjalne", co byłoby korzystne dla państwa (Tamże).

${ }^{104}$ Niepokój budzą ponadto: rosnące bezrobocie, pogłębiające się rozwarstwienie społeczne, znaczne dysproporcje dochodów ludności, ograniczenie dostępu do bezpłatnej opieki medycznej, duża liczba samobójstw; szerzej patrz: I. Kabzińska, Między pragnieniem ideału..., s. $14-52$.

105 Badacze zauważają, że migracje już dawno przestały być zjawiskiem dobrowolnym. Coraz więcej osób emigruje z powodów ekonomicznych, na skutek konfliktów wojennych i różnego rodzaju represji; patrz nр.: Р. П. Скорый, dz. cyt., s. 12. 
wych potrzeb ${ }^{106}$. Wśród zasadniczych przyczyn emigracji z Litwy można także wymienić „duże niesprawiedliwości społeczne” oraz „poważne trudności w prowadzeniu działalności biznesowej”" ${ }^{107}$. Wielu moich rozmówców twierdziło, że gdyby na Litwie lepiej płacono, emigracja byłaby znacznie mniejsza, nie miałaby też charakteru przymusowego, jak to się najczęściej dzieje obecnie. Zauważono też, że na Zachodzie, w ciągu jednego dnia można zarobić tyle, ile na Litwie dostaje się za miesiąc takiej samej pracy.

Rozmówcy zwracali uwagę, że gdyby nie emigracja, poziom bezrobocia w ich kraju byłby jeszcze wyższy. Negatywnie oceniano władze, które nie podejmują reform systemowych na rynku pracy, nie poszukują sposobów zahamowania wzrostu tego zjawiska. Emigracja jest przez nie traktowana jak panaceum na problem braku pracy na Litwie. Jeden z mężczyzn stwierdził, że duża skala emigracji, mającej głównie przyczyny ekonomiczne, świadczy o ułomności polityki państwa. Wiele osób podkreślało, że szczególnie niekorzystne są masowe wyjazdy ludzi młodych, wykształconych i przedsiębiorczych, wpływają one bowiem na zubożenie rodzimego rynku pracy $^{108} \mathrm{i}$ potencjału intelektualnego litewskiego społeczeństwa.

Mieszkańcy Litwy najczęściej wyjeżdżają do Wielkiej Brytanii, Irlandii, Niemiec, USA, do Rosji i na Białoruś, atrakcyjne są dla nich również kraje skandynawskie ${ }^{109}$. Dużą grupę wśród emigrantów, podobnie jak w przypadku innych krajów, stanowią ludzie młodzi (od 20 do 34 lat). Nie ma przy tym znaczących różnic między liczbą kobiet i mężczyzn decydujących się na emigrację (odnotowano jedynie niewielką przewagę mężczyzn) ${ }^{110}$. Wielu młodych wyjeżdża, ponieważ nie może znaleźć zajęcia na rodzimym rynku pracy. Są wśród nich zarówno osoby z wyższym wykształceniem (tendencja rosnąca), jak też robotnicy niewykwalifikowani, absolwenci szkół zawodowych ${ }^{111}$.

${ }^{106}$ Na tego rodzaju przyczyny wskazuje też np. G. Bolzane, dz. cyt. Dodajmy, że płace na Litwie są kilkakrotnie niższe niż w wielu krajach Europy Zachodniej; patrz np. A. Grynia, Przegląd podstawowych korzyści..., s. 13. W przekonaniu moich rozmówców, różnice mogą być nawet dziesięciokrotne.

107 Alarmujące dane...; patrz też: A. Akińczo, dz. cyt.

108 Na ten temat patrz też A. Grynia, Międzynarodowa migracja..., s. 40.

109 Tamże, s. 36; patrz też: E. Szałkowska, dz. cyt.

110 A. Grynia, Międzynarodowa migracja..., s. 37.

111 Tamże, s. 39. 
Litwa jest nie tylko krajem emigrantów. W poszukiwaniu pracy docierają tu przybysze $\mathrm{z}$ innych państw. Według jednego z litewskich przedsiębiorców, w najbliższych latach należy się spodziewać dużego napływu pracowników z Rosji, Ukrainy, Mołdawii, Białorusi oraz z poradzieckich republik azjatyckich ${ }^{112}$. Rzeczniczka Litewskiej Giełdy Pracy, Inga Buckaité, stwierdziła wprawdzie, że obecnie

Litwie nie grozi zalew taniej siły roboczej z Rosji, Ukrainy, Białorusi czy Mołdawii. [Dodała jednak, że] [w]szystko będzie zależało od sytuacji gospodarczej i pracodawców. Jeżeli (...) zaczną rosnąć płace, sytuacja może zmienić się. Na razie pracowników zagranicznych nie kuszą zarobki w naszym kraju. Ci sami Ukraińcy, Mołdawianie, mają po prostu możliwość wyboru - szukać szczęścia na Litwie czy np. w Anglii113.

Od 2007 r. litewskie urzędy wydały zgodę na zatrudnienie 20 tys. obcokrajowców. Wśród nich są głównie „osoby ze Wschodu”114. Dokładna liczba imigrantów nie jest znana, wielu z nich bowiem, jak mi mówiono, pracuje „na czarno”. Dane dotyczące imigracji, nawet jeśli mają jedynie szacunkowy charakter, świadczą o tym, że Litwa jest atrakcyjnym rynkiem pracy dla wielu cudzoziemców ${ }^{115}$. Wśród nich są nie tylko przybysze ze Wschodu, lecz także z Wielkiej Brytanii, Niemiec i z USA. Zdecydowaną większość imigrantów stanowią osoby w wieku 15-59 lat ${ }^{116}$.

Nasuwają się pytania: Czy przybysze z innych państw integrują się ze społeczeństwem litewskim i na jakich warunkach? Czy, jak ma to np. miejsce w wielu krajach Europy Zachodniej, tworzą zamknięte społeczności, etniczne getta, domagając się zarazem respektowania prawa do zachowania kulturowej odmienności i pomocy socjalnej? Jakie relacje łączą ich ze społeczeństwem przyjmującym? W jakim języku porozumiewają się z pracodawcami i innymi osobami? Niewielu z nich zapewne zna litewski, można

112 Wypowiedź tę cytuje R. Mickiewicz, Bezrobocie zwalczone - od przybytku głowa boli, „Kurier Wileński”, 23.11.2005, s. 8. Zdaniem cytowanego przedsiębiorcy, Litwie nie grozi „zalew robotników z Chin, Pakistanu, Afganistanu, Afryki” (Tamże). Według mnie, w niedalekiej przyszłości sytuacja może się radykalnie zmienić, zważywszy na rosnącą liczbę imigrantów z tych obszarów świata na kontynencie europejskim.

113 Tamże.

114 Ten kraj UE pustoszeje. Nie wiadomo, o jakie kraje chodzi. Czy pojęcie 'Wschód' ograniczone jest np. do dawnych republik radzieckich, czy też należy je rozumieć szerzej.

115 A. Grynia, Przegląd podstawowych korzyści..., s. 12.

116 Litwa. Imigracja, „Nasz Czas”, 4-17.05.2006, s. 4. W notce nie podano, jakiego rodzaju prace podejmowali imigranci, ani też, jakie środowiska i zawody reprezentowali. 
więc spodziewać się, że bariera językowa utrudnia integrację i adaptację do nowego dla imigrantów środowiska. Jakie są ich losy w pomieszanym świecie, do którego powstania sami się przyczyniają? Pojawia się też pytanie czy emigracja z Litwy będzie się nasilać? Kto zajmie miejsce litewskich emigrantów na rynku pracy, który dla wielu z nich okazał się niedostępny lub/i nieatrakcyjny ze względu na niskie płace? „Kluczowe dla przyszłości Litwy są [też] pytania: jaki charakter przybierze emigracja - trwały czy tylko czasowy oraz jak skutecznie państwo potrafi przeciwdziałać emigracji ludzi aktywnych, mobilnych i przedsiębiorczych?"117.

Pomieszany świat jest miejscem wielu nacji (kultur, języków, religii). Bywa, że relacje między nimi układają się bezkonfliktowo, często jednak mamy do czynienia z brakiem dialogu, chęci pokojowego rozwiązywania problemów. O tym jak trudno zbudować wielokulturowe społeczeństwo świadczy chociażby przykład Holandii ${ }^{118}$.Z podobnymi problemami borykają się jednak również inne kraje. Największe obawy budzą przybysze z krajów islamskich. Nie brakuje jednak również wystąpień (np. na forach internetowych) wyrażających sprzeciw wobec obecności imigrantów z Europy Środkowo-Wschodniej, przede wszystkim Polaków, Rumunów, Bułgarów i Romów ${ }^{119}$. Czy za niepożądanych gości uważani są również Litwini? Jaką wiedzą na temat Litwy dysponują mieszkańcy Europy Zachodniej? W jaki sposób emigranci z tego kraju przystosowują się do nowej dla nich rzeczywistości? Czy asymilują się, integrują, podlegają akulturacji? Jakie są ich rela-

117 Tamże.

118 Holandia przez długi czas uważana była za kraj otwarty na wszelką odmienność, budujący wzorcowe społeczeństwo wielokulturowe. Obecnie wielu Holendrów nie kryje, że nie chce już u siebie imigrantów, którzy nie respektują ideałów państwa europejskiego i jego wartości, nie uczą się niderlandzkiego, odmawiają integracji, narzucając własne wzory kulturowe, nie chcą pracować, wyciągają natomiast rękę po wszelkie formy pomocy społecznej, traktując je jako należne im świadczenia (więcej na ten temat patrz np.: I. Buruma, Murder in Amsterdam. The Death of Theo van Gogh and the Limits of Tolerance, Penguin, London 2006; P. Matusz-Protasewicz, Integracja z zachowaniem własnej tożsamości: Holenderska polityka wobec imigrantów, Wydawnictwo Uniwersytetu Wrocławskiego, Wrocław 2008; P. Scheffer, Druga ojczyzna. Imigranci w społeczeństwie otwartym, tłum. E. Jusewicz-Kalter, Wydawnictwo Czarne, Wołowiec 2010; K. Tomczyk, Dylematy multikulturalizmu we współczesnych społeczeństwach liberalno-demokratycznych. Wybrane zagadnienia, Uniwersytet Warszawski, Oficyna Wydawnicza ASPRA-JR, Warszawa 2007.

119 Przykładem może być portal internetowy założony przez holenderskiego polityka Geerta Wildersa, na którym można składać skargi na przybyszy z Europy Wschodniej. „Nacjonalistyczna strona wyzwoliła drzemiący w społeczeństwie strach przed obcymi"; E. Wesołowska, Płonący wieżowiec, „Angora”, 13.05.2012, s. 72. 
cje z rodzinami, które pozostały w kraju pochodzenia? Czy ulegają zmianom wyznawane przez nich dotychczas wartości i akceptowane wcześniej wzory zachowań? Jak przebiega proces adaptacji? Jaki wpływ wywiera migracja na tożsamość migrantów?

Moi rozmówcy, których bliscy wyjechali „za chlebem” do różnych krajów Europy Zachodniej, twierdzili, że przybysze z Litwy są cenieni jako pracownicy, szanowani, szybko też adaptują się do nowych warunków, dokładny opis ich problemów i środowisk, jakie tworzą emigranci z Litwy w krajach, które wybrali jako cel emigracji, wymaga jednak szczegółowych badań. Jak już wspomniałam, zdarza się, że są oni traktowani jak tania siła robocza, bezlitośnie wykorzystywani przez tych, dla których liczy się wyłącznie zysk. Wiele osób jednak znakomicie funkcjonuje w nowych warunkach. Świadczą o tym chociażby wypowiedzi moich rozmówców, których krewni przebywają na emigracji.

Emigranci, także ci z Litwy, żyją w pomieszanym świecie. Można o nim mówić w znaczeniu, jakie terminowi temu nadają mieszkańcy Białorusi: pogranicza kulturowego, wielokulturowych społeczności, gwałtownych zmian (w tym przypadku są one spowodowane migracją) oraz życia między przeszłością i teraźniejszością. Ta ostatnia kwestia dotyczy zwłaszcza emigrantów przymusowych, którzy z trudem odnajdują się w nowych warunkach. Tęsknią za tym, co „swoje”, bliskie, za rodziną, „oswojoną” przestrzenią, wzorami zachowań, do których byli przyzwyczajeni. Są zawieszeni między dawnym i nowym sposobem życia, Z trudem adaptują się do nowej rzeczywistości.

Jednym z powodów niechęci do imigrantów w krajach Europy Zachodniej są duże różnice kulturowe, pogłębiający się lęk przed „obcymi”, ale też zdecydowany opór wielu z nich przed integracją ze społeczeństwem przyjmującym (na jego zasadach). Imigranci są też postrzegani jako konkurencja na kurczącym się coraz bardziej rynku pracy i obciążenie dla podatników. Wypowiedzi moich rozmówców świadczą o tym, że taki sposób widzenia imigrantów nie jest obcy mieszkańcom Litwy. Wielu z nich krytycznie ocenia litewskich pracodawców, którzy chętnie zatrudniają imigrantów tylko dlatego, że mogą im zapłacić mniej niż Litwinom. Nie ma przy tym znaczenia, że ich kwalifikacje są często niższe od kwalifikacji pracowników litewskich. 
Jeśli imigracja będzie się nasilać, można się spodziewać pogłębiania konfliktów między przybyszami z innych krajów a społeczeństwem litewskim. W opinii niektórych badaczy migracja jest zjawiskiem korzystnym głównie dla krajów przyjmujących. Odnotowują one najczęściej wzrost ekonomiczny, ich gospodarka stabilizuje się, staje się bardziej konkurencyjna. W przypadku migracji niezwykle ważne są poza tym kwestie demograficzne. „Imigranci (...) są zazwyczaj młodsi i zdrowsi, dzięki czemu łagodzą narastające problemy demograficzne, związane ze starzeniem się społeczeństw (...)”120. Kraje takie jak Litwa, z których wyemigrowało wielu ludzi młodych, a znaczna część młodzieży zamierza wyjechać w najbliższej przyszłości, mogą natomiast mówić o „utra[cie] potencjału demograficznego"121. Dzięki imigrantom, wśród których jest wiele młodych osób, Litwa może wprawdzie odzyskać „swój potencjał demograficzny”, za jakiś czas może się jednak okazać, że zbyt duży przyrost naturalny wśród członków tych grup uznany zostanie przez społeczeństwo przyjmujące za zagrożenie dla jego przyszłości, stając się kolejnym źródłem konfliktów. Zjawiska te są dobrze znane w krajach Europy Zachodniej, m. in. we wspomnianej już przykładowo Holandii.

Wielu osobom migracja z pewnością przynosi korzyści. Pracodawcy traktują ją jako źródło taniej siły roboczej i lek na brak rąk do pracy w niektórych sektorach gospodarki. Korzystają z niej również ci, którzy znaleźli pracę za granicą i otrzymują za nią wynagrodzenie znacznie wyższe od tego, na jakie mogli liczyć w kraju, z którego przybyli (o ile udałoby się im tu znaleźć zatrudnienie). Praca i stosunkowo wysokie zarobki nie rekompensują jednak nierzadko takim osobom rozłąki z rodziną i miejscem, z którym było związane ich życie w kraju pochodzenia. Pojawia się poczucie wykorzenienia, „obcości”, tęsknoty za tym, co znane, „oswojone”. Moi rozmówcy podkreślali, że człowiek najlepiej czuje się we własnym domu, wśród bliskich, i nie powinien emigrować. Szczególnie niekorzystne są wyjazdy o charakterze przymusowym. Emigranci, jak wiadomo, budują swój dom w nowym miejscu. Wielu z nich twierdzi, że „wszędzie [jest] dobrze, bo świat stał się domem”122.

\footnotetext{
120 A. Grynia, Międzynarodowa migracja..., s. 31.

121 Tamże, s. 40.

${ }^{122}$ L. Domańska, Wszędzie dobrze, bo świat stał się domem, [w:] „Pod wielkim dachem nieba". Granice, migracje i przestrzeń we współczesnym społeczeństwie, pod red. W. Muszyńskiego i E. Sikory, Wydawnictwo Adam Marszałek, Toruń 2009, s. 15.
} 
Jak każde zjawisko społeczno-kulturowe także migracje mają swoje dobre i złe strony. Niektóre z nich starałam się ukazać w tym artykule (na przykładzie Republiki Litewskiej). Doświadczenia litewskiego społeczeństwa związane z emigracją, a także ze zjawiskiem imigracji, nie są ewenementem, należy jednak wziąć pod uwagę ich skalę, stosunek liczby emigrantów i imigrantów do liczby ludności kraju. Dalekosiężne skutki rosnącej emigracji i napływu imigrantów na Litwę są trudne do przewidzenia. Można spodziewać się znaczących zmian w strukturze etnicznej kraju, a także wzrostu różnego typu konfliktów, spowodowanych różnicami kulturowymi oraz rosnącą konkurencją na rynku pracy i pogłębiającymi się podziałami społecznymi, wynikającymi m. in. ze znacznej rozpiętości dochodów. Będą się też zapewne pogłębiać podziały na „swoich” i „obcych”, obejmujące różne grupy etniczne i społeczne (biedni i bogaci, mający pracę i bezrobotni, funkcjonujący w centrum lub na marginesie życia społecznego). Nastąpi też z pewnością dalsze pomieszanie świata. Będzie się on różnił zdecydowanie od tego, który stanowi jego biblijne pra-źródło, jak też od tego, w którym żyjemy obecnie.

\section{BIBLIOGRAFIA}

- Akińczo A., Rekordowa emigracja z Litwy; http://news.money.pl/artykul/rekordowa; emigracja; z; Litwy (dostęp: 05.02.2013).

- Alarmujace dane dot. emigracji na Litwie; http://wiadomosci,onet.pl/swiat/alarmujace-dane-dot-emigracji-na-litwie... (dostęp: 05.02.2013).

- Aleksijewicz S., Czarnobylska modlitwa. Kronika przyszłości, Wydawnictwo Czarne, Wołowiec 2012.

- Bin Gorion M. J., Żydowskie legendy biblijne, tłum. i opr. R. Stiller, Wydawnictwo KOS, Katowice 2009.

- Bolzane G., „Litwa nie jest dobrym krajem do życia”; http://www.presseurop.eu/pl /content/article/1498561-litwa-nie-jest-dobrym-krajem... (dostęp: 05.02.2013).

- Buruma I., Murder in Amsterdam. The Death of Theo van Gogh and the Limits of Tolerance, Penguin, London 2006.

- Bylina S., Motyw jedności słowiańskiej w Polsce późnego średniowiecza, [w:] Słowianie, Słowiańszczyzna - pojęcia i rzeczywistość, pod red. K. Handke, Fundacja Slawistyczna, Instytut Slawistyki Polskiej Akademii Nauk, Warszawa 2002.

- Cembrzyńska P., Wieża Babel. Nowoczesny projekt porządkowania świata i jego dekonstrukcja, Universitas, Kraków 2012. 
- Domańska L., Wszędzie dobrze, bo świat stał się domem, [w:] „Pod wielkim dachem nieba”. Granice, migracje i przestrzeń we współczesnym społeczeństwie, pod red. W. Muszyńskiego i E. Sikory, Wydawnictwo Adam Marszałek, Toruń 2009.

- Engelking A., Kołchoźnicy. Antropologiczne studium tożsamości wsi białoruskiej przełomu XX i XXI wieku, Wydawnictwo Naukowe Uniwersytetu Mikołaja Kopernika, Toruń 2012.

- Grynia A., Międzynarodowa migracja mieszkańców Litwy: Stan obecny i prognozy na przyszłość, „Rocznik Stowarzyszenia Naukowców Polaków Litwy”, t. 6, 2007.

- Grynia A., Przegląd podstawowych korzyści I kosztów wynikających z przynależności Litwy do UE, „Rocznik Stowarzyszenia Naukowców Polaków Litwy”, t. 6, 2007.

- Grynia A., Rynek pracy w dobie kryzysu: Litwa na tle Europy, [w:] Wpływ światowego kryzysu gospodarczego na kraje Europy Środkowej i Wschodniej. Aspekty gospodarcze i społeczne, pod. red. tejże, Uniwersytet w Białymstoku Filia w Wilnie, Centrum Doradztwa i Ekspertyz Gospodarczych, Warszawa-Wilno 2011.

- Ivanova T., „Mjašanaja mova - mjašany svet”, [w:] Pogranicza Białorusi w perspektywie interdyscyplinarnej, pod red. E. Smułkowej i A. Engelking, Wydawnictwo DiG, Warszawa 2007.

- Jankowiak M., Kilka uwag o czynnikach kształtujących tożsamość narodowa mniejszości białoruskiej na Łotwie (na przykładzie rejonu krasławskiego), [w:] Tożsamość - Język Rodzina. Z badań na pograniczu słowiańsko-bałtyjskim, pod red. A. Engelking, E. Golachowskiej i A. Zielińskiej, Instytut Slawistyki PAN, Warszawa 2008.

- Kabzińska I., Mały kraj masowej emigracji (Republika Litewska), [w:] Zawstydzona mąrość. Prace ofiarowane Ojcu Profesorowi Franciszkowi Rosińskiemu OFM, pod red. Małgorzaty Łoboz i Alana Tomasza Brzyskiego OFM, Franciszkańskie Wydawnictwo Św. Antoniego, Wrocław 2013.

- Kabzińska I.. Między pragnieniem ideału a rzeczywistościq. Polacy na Litwie, Białorusi i Ukrainie w okresie transformacji systemowej przełomu XX i XXI stulecia, Letter Quality, Warszawa 2009.

- Kabzińska I., O słowach, emocjach i „polskiej krzywdzie”, „Etnografia Polska” 1999, z. 1-2.

- Kabzińska I., „Pomieszany świat” jako kategoria opisu etnologicznego/antropologicznego, „Etnografia Polska” 2009, z. 1-2.

- Kabzińska I., Wśród „kościelnych Polaków”. Wyznaczniki tożsamości etnicznej (narodowej) Polaków na Białorusi, Letter Quality, Warszawa 1999.

- Ковкел И. И., История Беларуси, Гродно 1997.

- Kwaśniewski K., Marginalność etniczna i narodowa, „Sprawy Narodowościowe”, t. 16-17, 2000.

- Litwa. Imigracja, „Nasz czas”, 4-17.05.2006.

- Łuczyńska J., Rynek pracy na Litwie po wejściu do Unii Europejskiej, „Rocznik Stowarzyszenia Naukowców Polaków Litwy", nr 6, 2007.

- Matusz-Protasewicz P., Integracja z zachowaniem własnej tożsamości: Holenderska polityka wobec imigrantów, Wydawnictwo Uniwersytetu Wrocławskiego, Wrocław 2008. 
- Merska-Pietrak K., Nikt się nie buntuje „Angora” 20.01.2013.

- Mickiewicz R., Bezrobocie zwalczone - od przybytku głowa boli, „Kurier Wileński”, 23.11.2005.

- Mróz L., Swoi wśród innych, [w:] Polacy na Podolu, pod red. H. Strońskiego, Stowarzyszenie Uczonych Polskich Ukrainy, Kijów 2004.

- Mróz L., Syndrom pogranicza. Uwagi na temat badań świadomości etnicznej, „Polska Sztuka Ludowa. Konteksty" 1993, nr 3-4.

- Page Moch L., Moving Europeans: Migration in Western Europe since 1650, Indiana University Press, Bloomington 1992.

- Park R. E., Human Migration and the Marginal Man, „American Journal” 1928, nr 6.

- Paszkiewicz H., Powstanie narodu ruskiego, opr. L. Korczak, PAU, Kraków 1998.

- Pawluczuk W., Światopogląd jednostki w warunkach rozpadu społeczności tradycyjnej, PWN, Warszawa 1972.

- Pismo Święte Starego i Nowego Testamentu. Biblia Tysiąclecia, pod red. ks. K. Dynarskiego, Wydawnictwo Pallotinum, Poznań-Warszawa 1998.

- Salt J., Current Trends in International Migration in Europe, Council of Europe, Strasbourg 1997.

- Scheffer P., Druga ojczyzna. Imigranci w społeczeństwie otwartym, tłum. E. Jusewicz -Kalter, Wydawnictwo Czarne, Wołowiec 2010.

- Schlögel K., Środek leży na wschodzie. Europa w stadium przejściowym, tłum. A. Kopacki, Oficyna Naukowa, Warszawa 2005.

- Скорый Р. П., Основные направления иммиграционной политики стран Европейского Союза, [w:] Меняющаяся Европа. Проблемы этнокультурного взаимодействия, род red. М. Ю. Мартыновой, Российская Академия Наук, Москва 2006.

- Smułkowa E., Wokół pojęcia pogranicza. Wschodnie i zachodnie pogranicze Białorusi w ujęciu porównawczym, [w:] Pogranicza Białorusi w perspektywie interdyscyplinarnej, pod. red. E. Smułkowej i A. Engelking, Wydawnictwo DiG, Warszawa 2007.

- Straczuk J., Język a tożsamość człowieka w warunkach społecznej wielojęzyczności. Pogranicze polsko-litewsko-bialoruskie, Wydawnictwa UW, Warszawa 1999.

- Szałkowska E., Nadciaga nowa fala emigracji; http://kurierwilenski.lt/2011/01/10. nadciąga-nowa-fala-emigracji (dostęp: 05.02.2013).

- Ten kraj UE pustoszeje. Rekordowa emigracja; http://www.sfora.pl/Ten-kraj-UE-pustoszeje-Rekordowa-emigracja (dostęp: 05.02.2013).

- The Age of Migration: International Population Movement in the Modern World, pod red. S. Castles, M. Miller, The Guilford Press, New York 1993.

- Tilly Ch., Human Migration: Patterns and Politics, Indiana University Press, Bloomington 1978. 
- Tomczyk K., Dylematy multikulturalizmu we współczesnych społeczeństwach liberalno-demokratycznych. Wybrane zagadnienia, Uniwersytet Warszawski, Oficyna Wydawnicza ASPRA-JR, Warszawa 2007.

- Walaszek A., Migracje Europejczyków 1650-1914, Wydawnictwo Uniwersytetu Jagiellońskiego, Kraków 2007.

- Wesołowska E., Płonący wieżowiec, „Angora”, 13.05.2012.

- Zielińska A., Prestiż i funkcje języka polskiego w okolicach Baranowicz na Białorusi, „Etnografia Polska” 1993, z. 2.

- Zientara B., Świt narodów europejskich. Powstawanie świadomości narodowej na obszarze Europy pokarolińskiej, PIW, Warszawa 1985.

- Zowczak M., Biblia ludowa. Interpretacje wątków biblijnych w kulturze ludowej, Fundacja na Rzecz Nauki Polskiej, Warszawa 2000.

- Życzyńska-Ciołek D., Pomieszany świat, „Polska Sztuka Ludowa. Konteksty” 1996, nr 3-4.

- http://www.stat.gov.lt/lt/news/view/?id... (dostęp: 28.05.2008).

- http://www3,lrs.lt/pls/inter/w5_show?p_r... (dostęp: 16.05.2008).

\section{FROM THE BIBLICAL TOWER OF BABEL TO THE CONTEMPORARY “MIXED WORLD”}

There is a particular concept in the language of the inhabitants of Belarus, namely that of the mixed world. Its meaning is the equivalent of a "cultural borderland", the reality of multiculturalism. Mixed world refers to rapid changes as well as their effects (one of them is the coexistence of elements of an old and a new order). The author points out that the term can be used to good effect in scholarly studies as synonymous with "cultural borderland", "multiculturalism" or "intercultural spaces".

While asked about the origins of the mixed world, Belarussian people referred to the Biblical account of the Tower of Babel. It tells about God who "confounded the languages" of the builders of the Tower in order to punish their pride. The author remarks that the same account tells about the builders being scattered all over the earth, that being the origin of numerous migrations.

Migrations are inscribed in the history of the human world. The phenomenon is sure to grow in intensity, as it brings considerable benefits to many people. Lithuania is an example of a country where migration is of mass character. Recently for several years nearly one fifth of its population has left the country, and many others also declare their intention to leave. Referring to her own field research, the author points out the determinants as well as the results of mass migration from Lithuania. At the same time she shows that Lithuania is becoming an attractive labour market for many immigrants. This is the way in which, owing to various migrations the new mixed world is emerging, the world which is not free of conflicts and fears for the future. 